\title{
Ontogenesis of Thyrotropin-releasing Hormone in the Human Fetal Pancreas A Combined Radioimmunological and Immunocytochemical Study
}

\author{
Patrick Leduque, Sonia Aratan-Spire, Paul Czernichow, and Paul-M. Dubois \\ Centre National de la Recherche Scientifique, Unité associeê 559, Faculté de Médecine Lyon-Sud, 69921 Oullins Cédex; Institut National \\ de la Santé et de la Recherche Medicale U. 30, Hôpital des Enfants-Malades, 75743 Paris Cédex 15, France
}

\begin{abstract}
The ontogenesis of pancreatic thyrotropin-releasing hormone (TRH) in the human fetal gland was studied by radioimmunoassay or immunocytochemistry. The highest TRH concentrations $(1,508.5 \pm 382.3 \mathrm{pg} / \mathrm{mg}$ wet $\mathrm{wt})$ were detected between 6 and 8 wk of gestation. From 9 to 12 wk, TRH declined to $365.2 \pm 127.4 \mathrm{pg} / \mathrm{mg}$ wet wt and remained low thereafter $(96.1 \pm 28.9 \mathrm{pg} / \mathrm{mg}$ wet $\mathrm{wt})$. The immunocytochemical procedure was performed on semithin and thin sections from 12- to 19-wkold human fetuses. At the light microscope level, TRH was found interspersed among the islet cell clusters (12 wk), and later (16 wk) inside the typical islets of Langerhans. Consecutive semithin sections treated by TRH and insulin antisera showed the same immunoreactive cells. Electron microscopy showed TRH in B cell secretory granules. These results are consistent with an eventual implication of TRH in the endocrine regulation of metabolism or in the fetal development of pancreas.
\end{abstract}

\section{Introduction}

Recently thyrotropin-releasing hormone (TRH), ${ }^{1}$ a neuropeptide first detected in hypothalami and cerebral tissues (see ref. 1 for review), has also been found in the pancreas $(2,3)$. There is compelling evidence that TRH is located in the islets of Langerhans $(4,5)$, and more specifically within the $B$ cells producing insulin (6-8). Somewhat surprisingly, in the rat, a high TRH content has been detected on prenatal day 21 (9), reaching a peak on postnatal days $2-3$ and decreasing thereafter (10-13). Similarly, TRH-immunoreactive cells are most numerous in the early neonatal period; their number decreases later from day 8 onward (7). Large amounts of TRH have been identified in pancreatic tissues of human neonates (14), rapidly falling to adult levels (15). A similar pattern of development is thus speculated in humans.

However, to our knowledge, there is no information regarding the ontogenesis of pancreatic TRH in the human fetus. The present study was performed with the intent of identifying the gestational time of appearance and the distribution of TRH. The possibility that TRH may be present in the human fetal pancreas was examined with the methodology (immunocyto-

Address reprint requests to Dr. Leduque.

Received for publication 20 February 1986.

1. Abbreviations used in this paper: TRH, thyrotropin-releasing hormone.

J. Clin. Invest.

(c) The American Society for Clinical Investigation, Inc.

$0021-9738 / 86 / 10 / 1028 / 07 \quad \$ 1.00$

Volume 78, October 1986, 1028-1034 chemistry and radioimmunoassay) successfully employed to localize this peptide in normal (13), hypothyroid $(16,17)$, and streptozotocin-treated newborn (8) rat pancreas. In an effort to clarify the ultrastructural localization of TRH, we also pursued at the ultrastructural level the identification of the immunoreactive cell populations initially investigated by light microscopy (18-21).

\section{Methods}

Our study was carried out according to guidelines established by the National Ethical Committee. Human fetuses were obtained after legal abortions. Gestational age was carefully determined by the crown-rump length (22).

Materials. Pancreatic TRH was measured by radioimmunoassay from (a) 22 normal fetuses age 6-20 wk (Table I), and (b) two anencephalic female fetuses (26 and 32 wk old). To gain more information about TRH topography, we also studied a particular anatomical region of the pancreas (i.e., the lower posterior part of the head) from three normal fetuses age 13-15 wk (Table I). The immunocytochemical location of pancreatic TRH was investigated from eight 12-19-wk-old human fetuses (six females and two males). Pieces of pancreas were immediately excised and fixed for immunocytochemistry. Pancreatic fragments previously collected from 48 5-24-wk-old human fetuses (23) were also used.

Extraction of TRH from pancreatic tissue. Pancreatic fragments were stored at $-80^{\circ} \mathrm{C}$ until extracted. TRH was extracted according to a procedure previously described for mouse hypothalamus (24) and rat pancreas (13). Briefly, tissue was put in a cold $\left(2-4^{\circ} \mathrm{C}\right)$ medium consisting of $80 \%$ methanol $/ 14 \%$ distilled water $/ 6 \%$ acetic acid, in order to avoid any degradation of TRH by peptidases. Tissue was homogenized manually in glass Elvejheim potters (Ika-Verk, Stauffen i. Breisgau), sonicated, and kept for $24 \mathrm{~h}$ at $-30^{\circ} \mathrm{C}$. Homogenates were then centrifuged $(900$ $g$ for $10 \mathrm{~min}$ at $4^{\circ} \mathrm{C}$ ), and the supernatant was separated and evaporated. The dry extract was eluted in $90 \%$ aqueous methanol, and then were dried again. Samples were stored in methanol at $-30^{\circ} \mathrm{C}$. They were then evaporated to dryness, and taken up in $0.5 \mathrm{ml}$ phosphate buffer $(50 \mathrm{mM}$, $\mathrm{pH}$ 7.4) just before assay. Each sample was run in duplicate in the same assay.

TRH radioimmunoassay. Tissue levels of TRH were measured using a highly specific antibody obtained from Dr. C. Oliver (Centre Hospitalier et Universitaire Marseille-Nord, Marseille, France) (25) and the assay previously described (26). The antiserum was used at a final dilution of $1: 10,000$. The tracer used was [ ${ }^{125}$ I]TRH, prepared with the chloramine $T$ technique (27). [ $\left.{ }^{125} \mathrm{I}\right] \mathrm{TRH}$ was separated from free $\left[{ }^{125} \mathrm{I}\right]$ on a Sephadex G-10 column and further purified by cation exchange chromatography using SP-Sephadex C-25 and $15 \times 1.5-\mathrm{cm}$ column (Pharmacia Fine Chemicals, Uppsala, Sweden) equilibrated with $0.01 \mathrm{M}$ ammonium acetate, $\mathrm{pH}$ 5.5. Elution was done with a linear salt $(\mathrm{NaCl})$ gradient (initial condition, $0 \%$; final condition, $0.04 \mathrm{M}$ ).

Separation of bound antibody and free tracer was accomplished by charcoal-dextran treatment. The assay sensitivity averaged $13 \mathrm{pg} /$ tube, and intraassay and interassay coefficients of variation were 15 and $17.5 \%$, respectively.

Statistical methods. The values are presented as means \pm SEM of immunoreactive TRH, picograms per milligram wet weight of organ. Since our data could not be assumed to be normally distributed and the vari- 
Table I. TRH Concentrations in the Human Fetal Pancreas

\begin{tabular}{cll}
\hline & \multicolumn{2}{l}{ Anatomical regions of the fetal pancreas } \\
\cline { 2 - 3 } Age & Body & $\begin{array}{l}\text { Lower posterior part } \\
\text { of the head }\end{array}$ \\
\hline$w k$ & $p g / m g$ wet wt of organ & $p g / m g$ wet $w t$ of organ \\
$6-8$ & $1,508.5 \pm 382.3^{*}$ & - \\
$9-12$ & $365.2 \pm 127.4 \ddagger$ & - \\
$13-20$ & $96.1 \pm 28.9 \S$ & $111.2 \pm 23.2^{\prime \prime}$ \\
\hline
\end{tabular}

The results are given as means \pm SEM TRH concentration.

* Four, sex undefined.

$\ddagger$ Two males.

$\S$ Ten females and six males.

"Two females and one male.

ances of the independent groups could not be assumed to be equal, the Kruskal-Wallis one-way analysis of variance by ranks was employed to test the ontogenetic development of TRH (28). The null hypothesis is that the independent values of three age groups (6-8 wk, 9-12 wk, and 13-20 wk) come from the same continuous population. Similarly, the Mann-Whitney U test was used to test the TRH topography in two major anatomical regions of the pancreas (28). The null hypothesis is that the independent values of two tissue groups (i.e., the lower posterior part of the head and the body) represent a distribution that has underlying continuity.

Histological preparations. Location of pancreatic TRH was studied in sections that were fixed in $4 \% p$-formaldehyde and $0.5 \%$ glutaraldehyde for $2 \mathrm{~h}$ and postfixed in $1 \%$ osmium tetroxide for $1 \mathrm{~h}$ at $4^{\circ} \mathrm{C}$. Some of the tissue was only fixed in $1 \%$ osmium tetroxide for $2 \mathrm{~h}$ or $4 \% \mathrm{p}$-formaldehyde for $6 \mathrm{~h}$. After embedding in Araldite, semithin and thin sections were cut on an Ultrotome III (LKB Instruments, Inc., Bromma, Sweden), and stained immunocytochemically. Semithin sections were previously deresinated in a saturated solution of sodium hydroxide in methanol, and treated with $1-5 \%$ periodic acid (17). Thin sections were pretreated with sodium metaperiodate (17). We also used the pancreas of 5-24 wk-old human fetuses previously fixed in Bouin-Hollande sublimate and embedded in paraffin wax (23). Paraffin sections were deparaffinized in toluene and processed for immunocytochemistry.

Light microscopic immunocytochemistry. Semithin and paraffin sections were processed at room temperature in a humid chamber by the indirect immunoperoxidase method of Nakane and Pierce (29), with some modifications (17). The primary anti-hormone sera included antiTRH (1:2,000; No. IS4B11, a gift from Dr. D. Grouselle and Dr. A. Tixier-Vidal, Collège de France, Paris, France); anti-insulin (1:5,000, No. 24-2), and anti-COOH-terminal glucagon (1:2,500, No. GB 5667) (a gift from Dr. R. Assan, Hôpital Bichat, Paris, France); and anti-somatostatin (1:1,000, No. 19608, a gift from Dr. M. P. Dubois, Nouzilly, France). All anti-hormone sera were raised in rabbits. Goat anti-rabbit immunoglobulin $\mathrm{G}$ conjugated to peroxidase was purchased from Nordic Immunology (London).

Electron microscopic immunocytochemistry. The immunocytochemical reaction on thin sections with the peroxidase-antiperoxidase complex (30) was based on the method described by Moriarty and Halmi (31). Peroxidase-antiperoxidase complex (the antiperoxidase made in rabbit) was purchased from Dako-immunoglobulins a/s (Copenhagen, Denmark).

Anti-hormone sera specificity tests. The anti-hormone sera have been thoroughly tested and described in detail elsewhere (17-21, 32). Nevertheless, the immunocytochemical controls were repeated for this study. The specificity of the staining was confirmed by demonstrating complete blockade of the positive reaction in the sections when they were incubated with anti-TRH serum depleted of anti-TRH reactivity by treatment with a solid-phase TRH immunoabsorbent. Technical details were described elsewhere (17). Furthermore, absorption of the anti-TRH serum with pancreatic (insulin, proinsulin $\mathrm{C}$ peptide, glucagon, glicentin, so- matostatin, pancreatic polypeptide) and brain (gonadoliberin, lysine-vasopressin, oxytocin, $\alpha$-melanocyte-stimulating hormone, prolactin, corticotropin-releasing factor) hormones or hormone fragments (TRH free acid, $p$-Glu-His $\mathrm{OH}$, Glu-His $\mathrm{OH}$, His-Pro-Diketopiperazine) had no effect on immunostaining. To eliminate the immunoreaction with the anti-insulin, anti-glucagon, or anti-somatostatin serum, addition of 15 $\mathrm{nmol}$ insulin, $55 \mathrm{nmol}$ glucagon, and $225 \mathrm{nmol}$ somatostatin were necessary, respectively. To prevent labeling of islet cells by electrostatic and hydrophobic binding of immunocytochemical reagents with tissue or by cross-reacting antibodies $(33,34)$, all anti-hormone sera were used at high dilutions (as indicated above).

Morphometry. A mean granule profile diameter per cell type was computed from measurements taken from standard enlargements of the electron micrographs. It was estimated with the aid of an image analyzer (Kontron Analytical, Everett, MA) after drawing the outlines of secretory granules. The mean values (in nanometers) of granule profile diameter were characterized with the aid of the $95 \%$ confidence limits $($ mean $\pm 1.96 S D / \sqrt{n})$.

\section{Results}

\section{$T R H$ radioimmunoassay.}

As shown in Table I, pancreatic TRH concentrations (picograms per milligram wet weight \pm SEM) were high between 6 and 8 wk of gestation $(1,508.5 \pm 382.3)$, declined to $365.2 \pm 127.4$ from 9
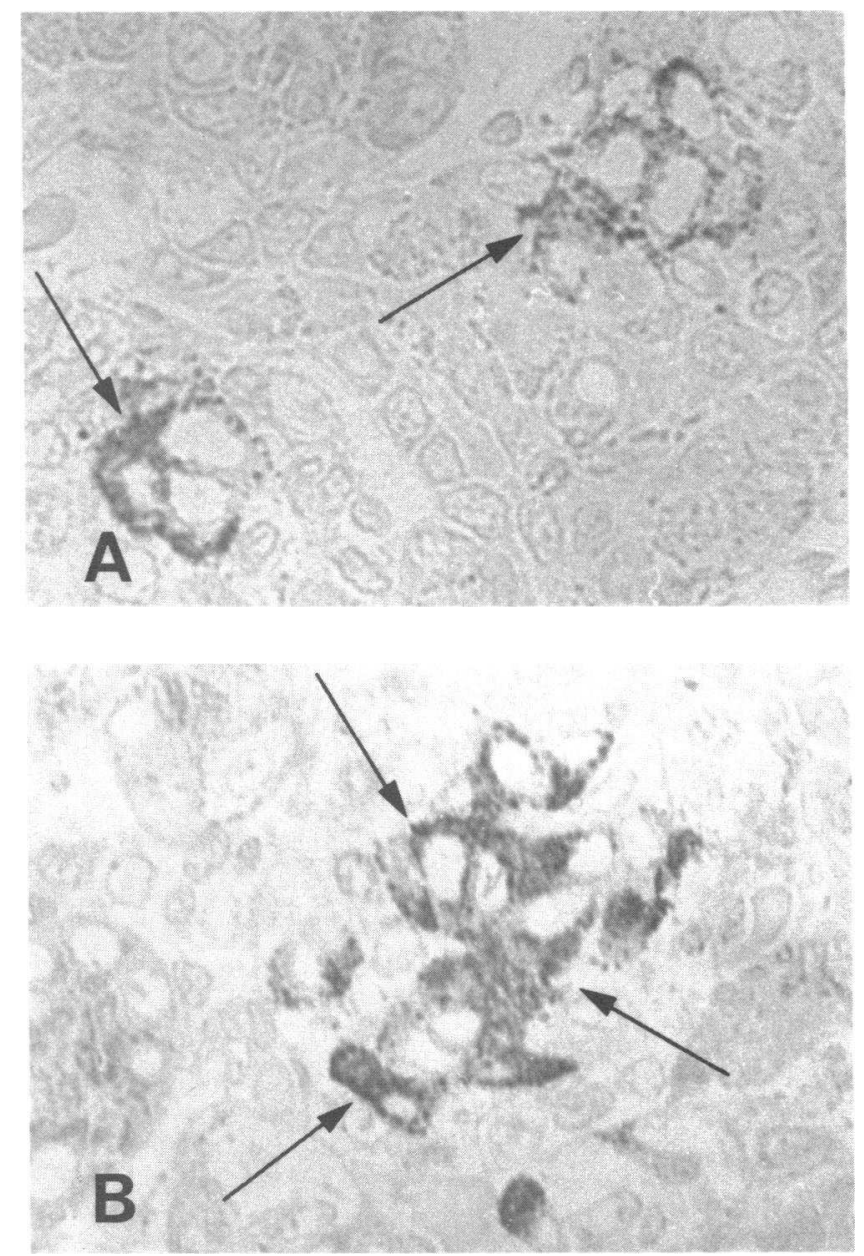

Figure 1. Light microscope location of islet TRH immunoreactive cells. $(A)$ 12-wk-old human fetus: the positive cells (arrows) are interspersed among the cell clusters; $\times 1,600$. (B) 16-wk-old human fetus: the positive cells (arrows) are observed in the central portion of the islets. $\times 1,400$. 

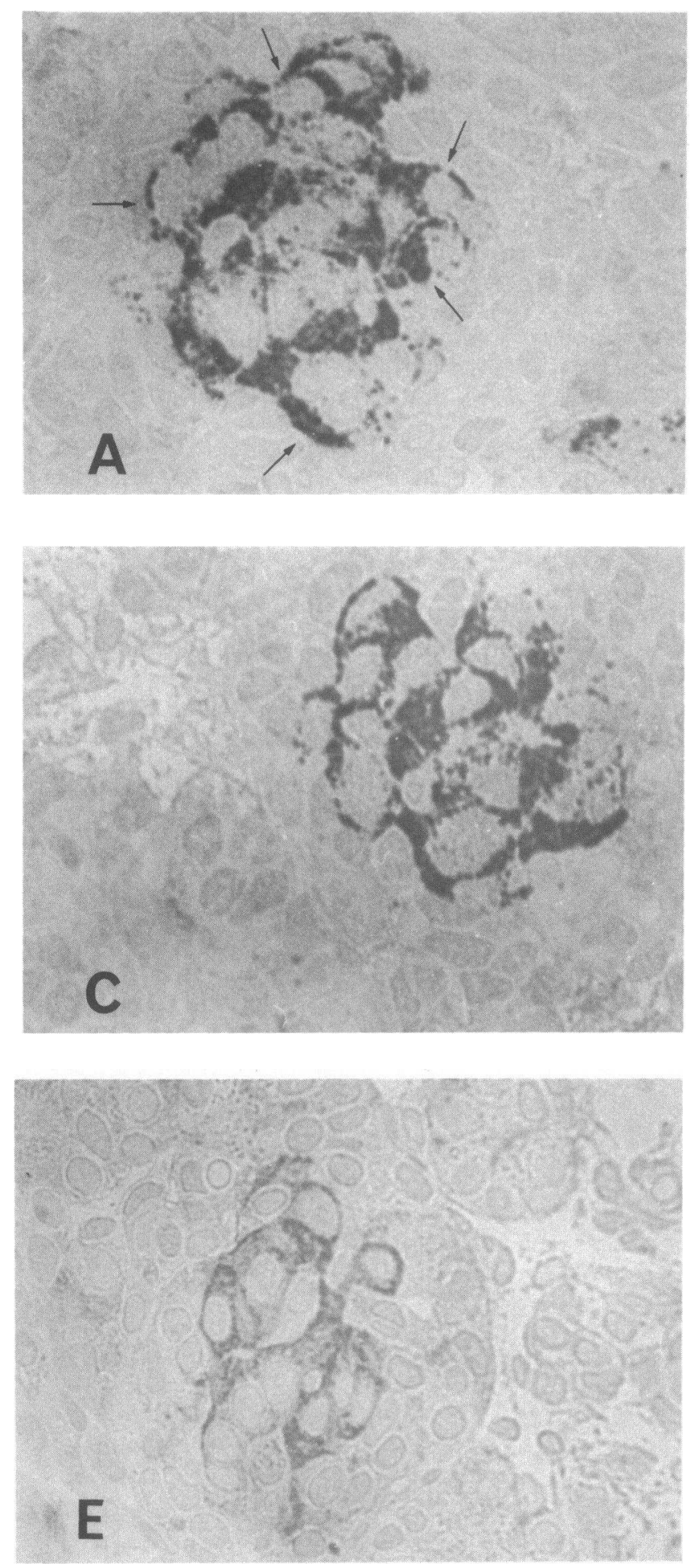

Figure 2. Light microscope relationships of TRH with other islet hormones. 16-wk-old human fetus. Serial sections processed for immunocytochemistry with anti-TRH. $(A, C, E)$, anti-insulin $(B, \times 1,600)$, anti-glucagon $(D, \times 1,500)$ or anti-somatostatin $(F, \times 1,400)$ serum.

to $12 \mathrm{wk}$ and remained low thereafter $(96.1 \pm 28.9$ between 13 and 20 wk). The Kruskal-Wallis test revealed that the TRH concentrations were not the same in the three age groups, since the TRH concentration was highest in the 6-8-wk group, intermediate in the 9-12-wk group, and was lowest in the 13-20-wk group $(H \geqslant 10.31 ; P<0.01)$. We conclude that the specified
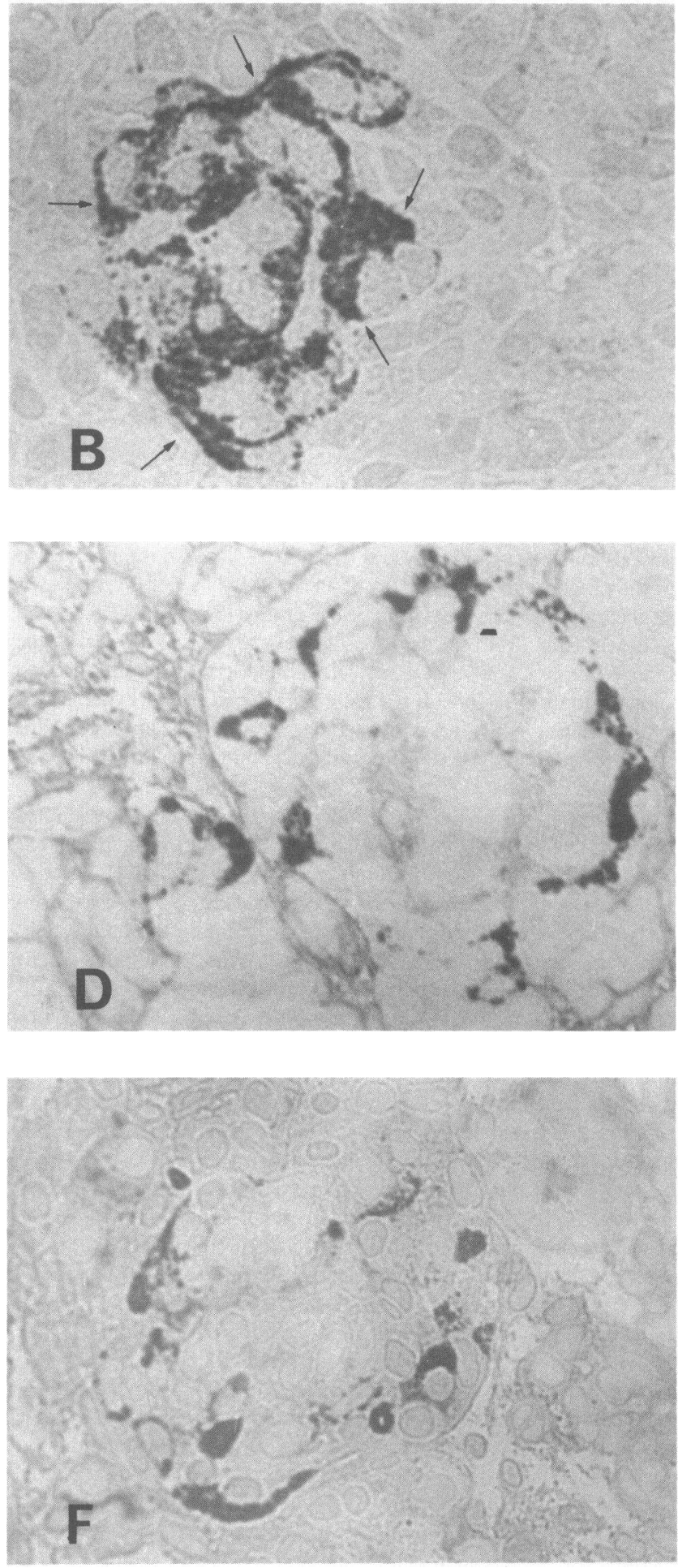

The same cell population (arrows) is positive for both TRH and insulin. In addition, the TRH immunoreactive cells are distinct from glucagon-containing cells or somatostatin-containing cells.

three age groups differ in the TRH content. In contrast, the Mann-Whitney $U$ test revealed that the TRH concentrations were the same in the lower posterior part of the head (111.2 \pm 23.2$)$ and the body $(96.1 \pm 28.9)$ between 13 and 20 wk (Table I). Indeed, we see that $U \leqslant 7$ has a probability of occurrence of $P=0.258$. Thus, the data support the null hypothesis. 
Finally, TRH was also found in the pancreata of two anencephalic fetuses (129 pg/mg, 26 wk old; $55 \mathrm{pg} / \mathrm{mg}, 32 \mathrm{wk}$ old). The amounts of TRH measured are comparable to the values found in the 13-20-wk group of normal fetuses.

\section{Immunocytochemistry of TRH}

Comparison of fixatives. Of the procedures for tissue preparation tested, only a mixture of $p$-formaldehyde and glutaraldehyde followed by a secondary fixation with osmium tetroxide were successful for detecting TRH immunoreactivity in the human fetal pancreas (Fig. 1, $A$ and $B$ ). In contrast, the anti-islet hormone (insulin, glucagon, and somatostatin) sera gave positive immunostaining whatever the fixation procedures. Unfortunately, preliminary light microscopic studies revealed that the antigenicity of TRH was destroyed by the fixation with BouinHollande sublimate. Consequently, pancreatic fragments previously collected from 48 5-24-wk-old human fetuses (23) could not be used.

Location of TRH-immunoreactive cells. At the light microscope level, intense TRH immunoreactivity was observed between 12 and 19 wk of gestation in the pancreatic parenchyma. The staining was confined to the islet cell clusters at the 12th week (Fig. $1 A$ ), and to the typical islets from the end of the fourth month (Fig. $1 B$ ). The TRH-immunoreactive cells tended to accumulate in the central portion of each islet, and were surrounded by a rim of unstained cells (Fig. $1 B$ ). The reaction product was present in all the pancreatic islets of the male and female fetuses investigated. The exocrine tissue of the fetal pancreas was unstained. Also, no nerve cells or fibers within the pancreas contained TRH-immunoreactivity.

Topographical relation of TRH with other islet hormones. In the light microscopic-immunocytochemical study, we confirmed the pattern of development of insulin immunoreactivity, glucagon immunoreactivity, and somatostatin immunoreactivity. As previously reported (18-21), immunoreactive cells were interspersed among the islet cell clusters at the 12th week of gestation, and still later ( $16 \mathrm{wk}$ ) inside the recognizable islets of Langerhans. At this stage, insulin immunoreactivity was observed in the central portion of the islets while glucagon immunoreactivity and somatostatin immunoreactivity were confined to the peripheral parts (Fig. 2, $B, D$, and $F$ ). In the electron microscopic-immunocytochemical study, all morphological features of the various cells revealed by conventional electron microscopy (Fig. 3) were recognized after the immunocytochemical reaction (Fig. 4).

When semithin sections adjacent to those processed with the anti-TRH serum were incubated with the anti-insulin serum, it was observed that both anti-hormone sera stained the same population of endocrine cells (Fig. 2, $A$ and $B$ ). In contrast, the TRH-immunoreactive cells were distinct from glucagon-containing cells or somatostatin-containing cells (Fig. 2, $C-F$ ). At the electron microscope level, the immunocytochemical obser-

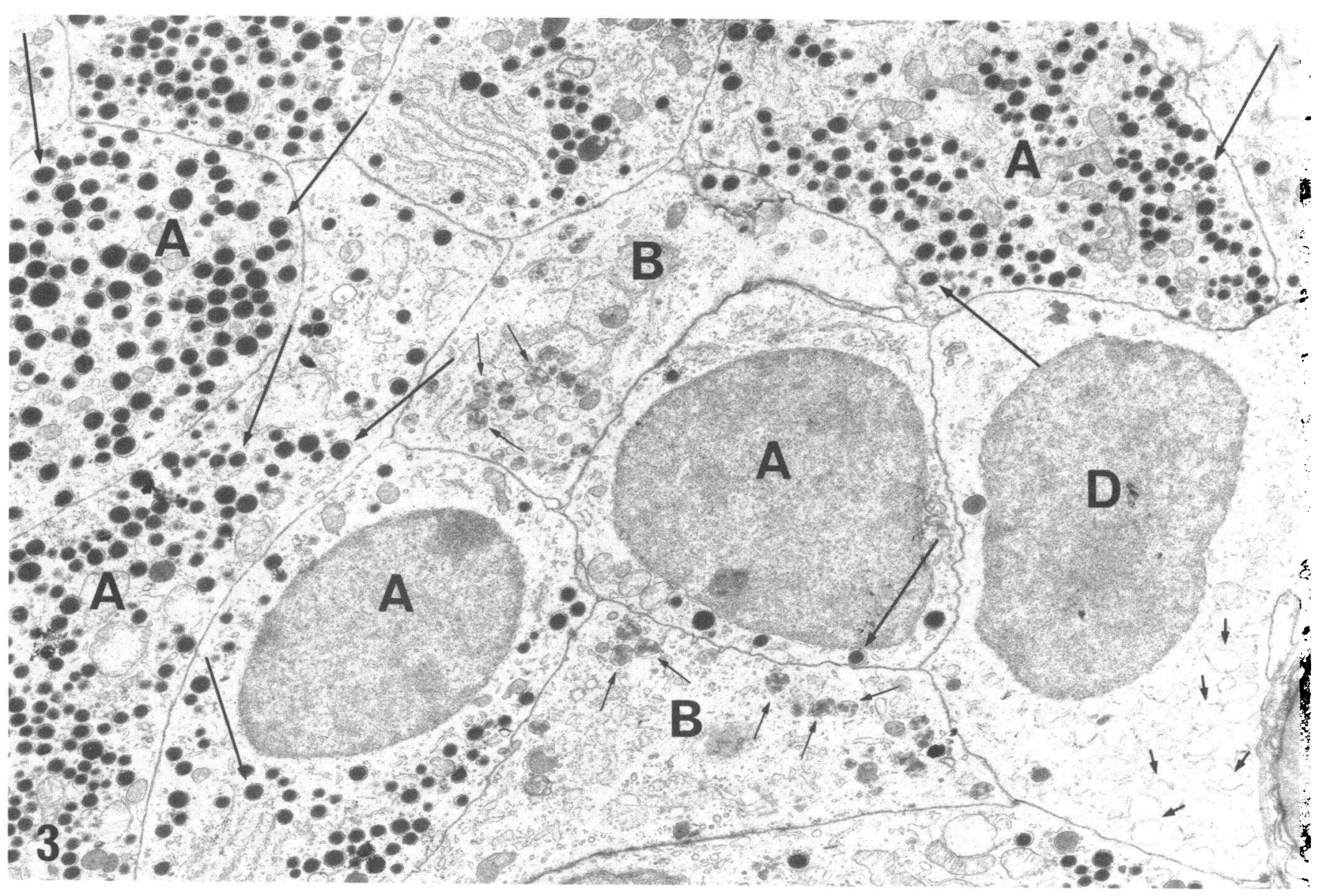

Figure 3. Ultrastructural differences between the islet secretory granules. 14-wk-old human fetus. The A cells $(A)$ have a typical appearance with an eccentric electron-dense core and a thin halo (long arrows), whereas the B cells $(B)$ have a crystalloid core and a broad halo (short arrows). The $\mathrm{D}$ cells $(D)$ contain large granules with clear contents surrounded by a broken limiting membrane (arrowheads). $\times 11,500$. 

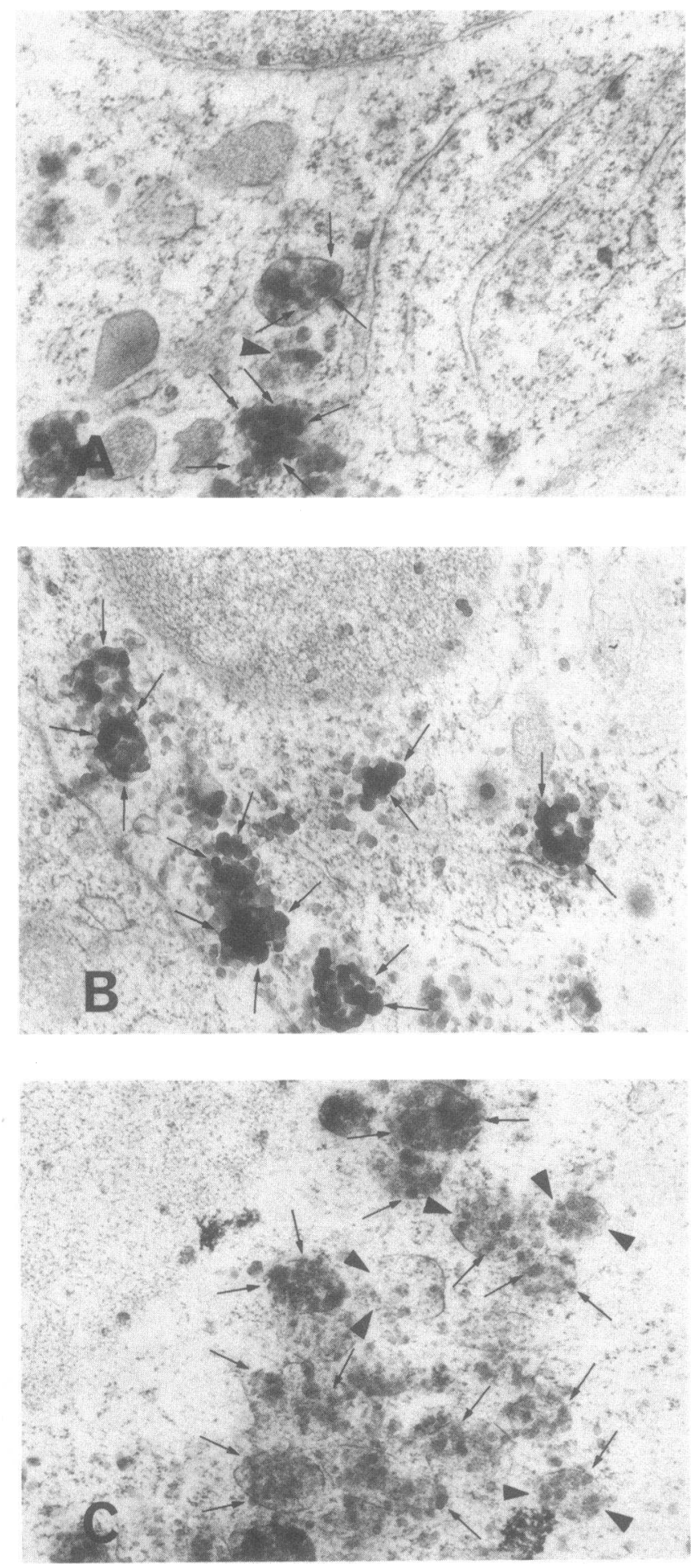

Figure 4. Electron microscopic-immunocytochemical identification of islet cell types. 14-wk-old human fetus. $(A)$ portion of an insulin positive cell: the reaction product (arrows) is deposited over the B cell secretory granules; a paracrystalline core (arrowhead); $\times 34,000$. (B) portion of a glucagon-positive cell: the reaction product (arrows) is densely packed over the A cell granule core; $\times 27,000$. $(C)$ portion of a somatostatin-positive cell: the reaction product (arrows) is confined to $\mathrm{D}$ cell secretory granules; note the broken limiting membranes (some indicated by arrowheads); $\times 23,000$.

vations revealed that TRH was found in the B cells characterized by the presence of secretory granules with an electron-opaque paracrystalline core (Fig. 5). The antigen-antibody complex identified by 4-chloro-1-naphthol appeared as small (at least 30 $\mathrm{nm}$ in diameter) electron-dense precipitates. With the anti-TRH serum, deposits were found over all the secretory granules (Fig. 5). Measurements made on B cells containing at least 30 secretory granules showed that the granule profile diameter varied considerably within a given cell and between different cells, and ranged from 300 to $600 \mathrm{~nm}$; their size distribution is shown in Fig. 6. The mean value (nanometers \pm confidence limits, 95\%) of the profile diameter was $442 \pm 5.04$.

\section{Discussion}

The present report is the first description of the development and the location of TRH in the human fetal pancreas. Somewhat surprisingly, high concentrations of TRH are detected during fetal life, particularly between 6 and 8 wk. TRH values then decrease significantly between 9 and $20 \mathrm{wk}$. The current study also demonstrates that TRH is found in the insulin-containing cells. A major potential problem is the interpretation of these findings with regard to the specificity of the anti-TRH serum. In the radioimmunoassay, this antiserum cross-reacts with $\left[{ }^{3} \mathrm{H}\right] \mathrm{TRH}$ (32). There is no significant reactivity in the TRH assay by other structurally related peptides including TRH free acid ( $p$-Glu-His-Pro $\mathrm{NH}_{2}$ ), p-Glu-His $\mathrm{OH}$, His-Pro $\mathrm{OH}$, lysinevasopressin, gonadoliberin and somatostatin (32). ${ }^{2}$ The control of specificity of the immunocytochemical reaction established that the anti-TRH serum reacted with the TRH molecule, and had no affinity to the heterologous antigens (pancreatic or brain peptides). Also, the staining of B cells by this antiserum was unaffected by incubation with TRH-degradation products. These results are in agreement with our previous study of cells storing TRH and insulin in the adult rat pancreas (17).

The combined use of immunocytochemistry and radioimmunoassay proves to be an invaluable tool for a complete study of the ontogenesis of TRH. The first technique, however, is inevitably dependent on the procedures for tissue preparation. The antigenicity of TRH is not well preserved after immersion in the conventional liquid fixatives (e.g., Bouin-Hollande sublimate, p-formaldehyde, or osmium tetroxide). In contrast, a mixture of $p$-formaldehyde and glutaraldehyde followed by a secondary fixation with osmium tetroxide are excellent for preserving the TRH immunoreactivity in the human fetal pancreas. Similar results have been obtained in the adult rat pancreas (17).

TRH is found in the B cells of the islets and possibly coexists with insulin in the same secretory granules. Coexistence of peptides in pancreatic endocrine cells can generally be explained by the fact that they arise from the same precursor. Thus, there are reports of glicentin- and gastric inhibitory polypeptide-like immunoreactants in the pancreatic A cells producing glucagon in human fetus $(20,21,35,36)$. There are other cases, however, of coexistence of unrelated peptides in the sense that they are chemically dissimilar and do not appear to be derived from the same precursor (see ref. 37 for review). To date, there is no reason to suspect that TRH and insulin share the same precursor $(38-42)^{3}$

2. No cross-reaction is seen with the artificial peptides Gln-His-Pro-GlyLys-Arg-Phe and Ser-Lys-Arg-Gln-His-Pro-Gly-Lys-Arg-Phe (FaivreBauman, A., and D. Grouselle, personal communication).

3. Using an antibody that specifically recognizes the rat hypothalamic TRH precursor, Jackson's group has recently elucidated its cDNA sequence, which encodes a protein with a molecular mass close to 30,000 $(41,42)$. 


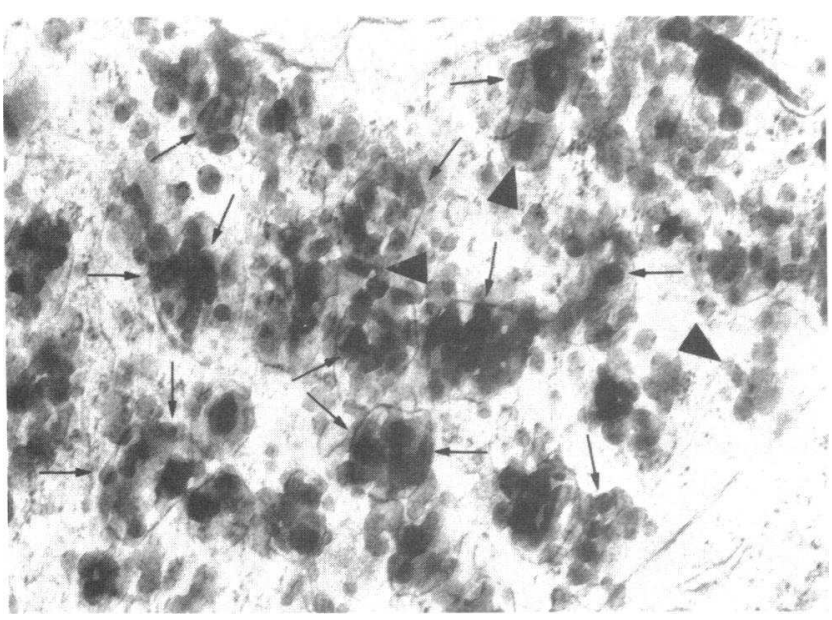

Figure 5. Electron micrograph of a portion of an islet B cell immunostained with anti-TRH serum. The reaction product (arrows) is present principally to cores of secretory granules; paracrystalline cores (arrowheads); $\times 35,000$.

Ontogenesis and ultrastructural features of B cells have previously been examined in the human fetal pancreas. Granulated (differentiated) endocrine cells are present during the early stages (10-11 wk) of gestation, and the morphological characteristics are strongly suggestive of B cells (43). By radioimmunoassay, it has been documented that insulin synthesis and storage are present at 14 wk (44). In this study, however, the time of origin of immunoreactive insulin was not determined. Using immunocytological techniques, in contrast, it has been observed that insulin-containing cells are present from $12 \mathrm{wk}$ (18). While the methods for determining the age of the fetuses do not exclude slight variations, there is good agreement between "the birth date" of insulin and the data obtained by morphological techniques. In this context, it would be of interest to determine if TRH precedes insulin in the developmental pattern in the B cell. Although our data do not allow any comparison between TRH and insulin ontogenesis, note that insulin is absent in the extract of the pancreas of a 9-wk-old fetus (44). Consequently, our radioimmunological findings seem to indicate that TRH may arise earlier than insulin.

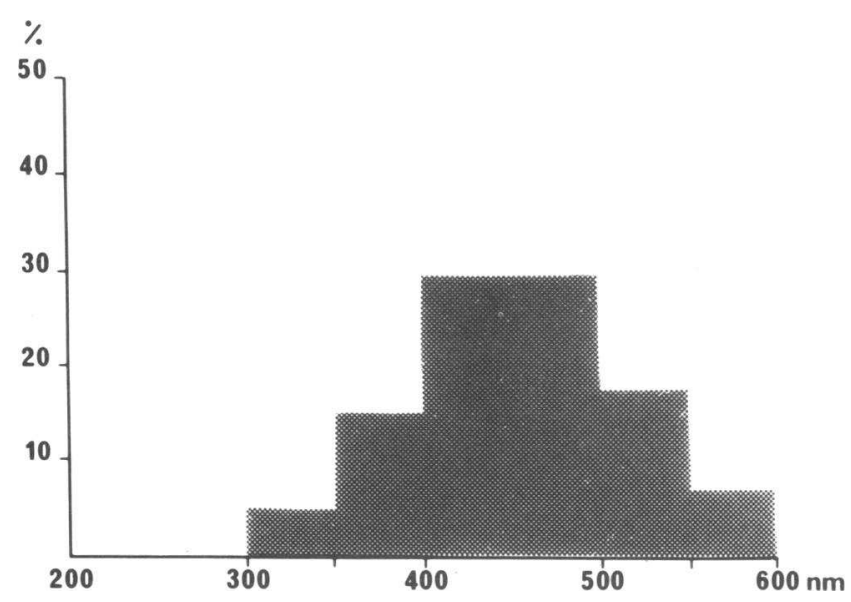

Figure 6. Distribution of granule profile diameters in B cells of the human fetal pancreas.
TRH has been detected in the human fetal brain as early as 4.5 wk of gestation (45). However, the pancreas probably produces TRH. One study has shown the in vitro synthesis of TRH by rat pancreatic cells, using $\left[{ }^{14} \mathrm{C}\right]$ histidine incorporation and radioimmunoassay (46). In accordance with this hypothesis, we found TRH in anencephalic fetuses. The colocalization with insulin stimulates the hypothesis (47) that TRH may play a role in insulin physiology. However, it is not inconceivable that other roles may exist. Certainly, high amounts of TRH at an early stage (6 wk) in the human fetal pancreas suggest a possible, as yet undefined, activity in the regulation of differentiation and/ or growth of fetal cells.

\section{Acknowledgments}

The authors thank Dr. M. Dumont, Hôpital de la Croix-Rousse, Dr. J. M. Thoulon, Hôtel Dieu, Dr. D. Dargent, Hôpital Edouard Herriot, Dr. M. Bethenod, Hôpital Debrousse, Lyon, and Dr. J. Freycon, Hôpital Bellevue, Saint-Etienne, for their cooperation. The authors also thank F. Hemming for checking the manuscript and M. Tschora for expert secretarial assistance.

\section{References}

1. Jackson, I. M. D. 1982. Thyrotropin-releasing hormone. N. Engl. J. Med. 306:145-154.

2. Morley, J. E., T. J. Garvin, A. E. Pekary, and J. M. Hersham. 1977. Thyrotropin-releasing hormone in the gastrointestinal tract. Biochem. Biophys. Res. Commun. 79:314-318.

3. Leppäluoto, J., F. Koivusalo, and R. Kraama. 1978. Thyrotropinreleasing factor: distribution in neural and gastrointestinal tissues. Acta Physiol. Scand. 104:175-179.

4. Martino, E., Å. Lernmark, J. Seo, D. F. Steiner, and S. Refetoff. 1978. High concentration of thyrotropin-releasing hormone in pancreatic islets. Proc. Natl. Acad. Sci. USA. 75:4265-4267.

5. Koivusalo, F., J. Leppäluoto, M. Krip, and H. Rajaniemi. 1981. Presence of TRH immunoreactivity in marginal islet cells in rat pancreas. Acta Endocrinol. 97:398-404.

6. Kazumi, T., M. Utsumi, Y. Hirose, K. Ishihara, H. Makimura, K. Ejiri, H. Taniguchi, and S. Baba. 1982. Protection by nicotinamide against streptozotocin-induced reduction in pancreatic TRH. Acta Endocrinol. 101:570-573.

7. Kawano, H., S. Daikoku, and S. Saito. 1983. Location of thyrotropin-releasing hormone-like immunoreactivity in rat pancreas. Endocrinology. 112:951-955.

8. Aratan-Spire, S., B. Wolf, B. Portha, D. Bailbe, and P. Czernichow. 1984. Streptozotocin treatment at birth induces a parallel depletion of thyrotropin-releasing hormone and insulin in the rat pancreas during development. Endocrinology. 114:2369-2373.

9. Lamberton, R. P., R. M. Lechan, and I. M. D. Jackson. 1984. Ontogeny of thyrotropin-releasing hormone and histidyl proline diketopiperazine in the rat central nervous system and pancreas. Endocrinology. 115:2400-2405.

10. Koivusalo, F., and J. Leppäluoto. 1979. High TRH immunoreactivity in purified pancreatic extracts of fetal and newborn rats. Life Sci. 24:1655-1658.

11. Martino, E., H. Seo, Å. Lernmark, and S. Refetoff. 1980. Ontogenetic patterns of thyrotropin-releasing hormone-like material in rat hypothalamus, pancreas and retina: selective effect of light deprivation. Proc. Natl. Acad. Sci. USA. 77:4345-4348.

12. Engler, D., M. F. Scanlon, and I. M. D. Jackson. 1981. Thyrotropin-releasing hormone in the systemic circulation of the neonatal rat is derived from the pancreas and other extraneural tissues. J. Clin. Invest. 67:800-807. 
13. Aratan-Spire, S., B. Wolf, and P. Czernichow. 1984. Developmental pattern of TRH-degrading activity and TRH content in rat pancreas. Acta Endocrinol. 106:102-108.

14. Koivusalo, F. 1981. Evidence of thyrotropin-releasing hormone activity in autopsy pancreata from newborns. J. Clin. Endocrinol. Metab. 53:734-736.

15. Øystein, L., K. F. Hanssen, E. Aadland, and T. Sand. 1983. Thyrotropin-releasing hormone immunoreactivity in the gastrointestinal tract of man. J. Clin. Endocrinol. Metab. 56:524-529.

16. Wolf, B., S. Aratan-Spire, and P. Czernichow. 1984. Hypothyroidism increases pancreatic thyrotropin-releasing hormone concentrations in adult rats. Endocrinology. 114:1334-1337.

17. Leduque, P., B. Wolf, S. Aratan-Spire, P. M. Dubois, and P. Czernichow. 1985. Immunocytochemical location of thyrotropin-releasing hormone (TRH) in the B-cell of adult hypothyroid rat pancreas. Regul. Pept. 10:281-292.

18. Dubois, P. M., C. Paulin, R. Assan, and M. P. Dubois. 1975. Evidence for immunoreactive somatostatin in the endocrine cells of human foetal pancreas. Nature (Lond.). 256:731-732.

19. Chayvialle, J. A., C. Paulin, P. M. Dubois, F. Descos, and M. P. Dubois. 1980. Ontogeny of somatostatin in the human gastrointestinal tract, endocrine pancreas and hypothalamus. Acta Endocrinol. 94:1-10.

20. Leduque, P., C. Gespach, J. C. Brown, G. Rosselin, and P. M. Dubois. 1982. Ontogeny of gastric inhibitory peptide in the human gastrointestinal tract and endocrine pancreas. Acta Endocrinol. 99:112-121.

21. Leduque, P., A. J. Moody, and P. M. Dubois. 1982. Ontogeny of immunoreactive glicentin in the human gastrointestinal tract and endocrine pancreas. Regul. Pept. 4:261-274.

22. Hamilton, W., J. Boyd, and H. Mossman. 1972. Growth of the embryo and fetus. In Human Embryology. W. Heffer and Sons, editors. Williams \& Wilkins, Div. of Waverly Press, Inc. Company, Baltimore, MD. 174-191.

23. Leduque, P., C. Paulin, J. A. Chayvialle, and P. M. Dubois. 1981. Immunocytological evidence of motilin- and secretin-containing cells in human fetal gastroenteropancreatic system. Cell Tissue Res. 218:519527.

24. Faivre-Bauman, A., D. Grouselle, A. Nemeskery, and A. TixierVidal. 1978. Ontogenesis of thyroliberin in the mouse hypothalamus. Brain Res. 154:382-387.

25. Eskay, R. L., C. Oliver, J. Warberg, and J. C. Porter. 1976. Inhibition of degradation and measurement of immunoreactive thyrotropin-releasing hormone in rat blood and plasma. Endocrinology. 98:269277.

26. Jackson, I. M. D., and S. Reichlin. 1974. Thyrotropin-releasing hormone (TRH): distribution in hypothalamic and extrahypothalamic brain tissues of mammalian and submammalian chordates. Endocrinology. 95:855-862.

27. Hunter, W. M., F. C. Greenwood, and J. S. Glover. 1963. The preparation of ${ }^{131} \mathrm{I}$-labeled human growth hormone of high specificity radioactivity. Biochem. J. 89:114-123.

28. Siegel, S. 1956. Nonparametric statistics. McGraw-Hill, Inc., New York. 1-312.

29. Nakane, P. K., and G. B. Pierce. 1966. Enzyme-labeled antibodies: preparation and application for the localization of antigens. J. Histochem. Cytochem. 14:929-931.

30. Sternberger, L. A., P. H. Hardy, J. J. Cuculis, and H. G. Meyer. 1970. The unlabeled antibody-enzyme method of immunohistochemistry. Preparation and properties of soluble antigen-antibody complex (horseradish peroxidase-antihorseradish peroxidase) and its use in identification in spirochetes. J. Histochem. Cytochem. 18:315-333.

31. Moriarty, G. C., and N. S. Halmi. 1972. Electron microscopic study of the adrenocorticotropin producing cell with the use of unlabeled antibody and the soluble peroxidase-antiperoxidase complex. J. Histochem. Cytochem. 20:590-603.

32. Grouselle, D., A. Faivre-Bauman, and A. Tixier-Vidal. 1978. A radioimmunoassay for thyroliberin (TRH). Comparison with a TRH radio-receptor assay. Neurosci. Lett. 7:7-15.

33. Grube, D., and E. Weber. 1980. Immunoreactivities of gastrin (G-) cells. I. Dilution-dependent staining of G-cells by anti-sera and nonimmune sera. Histochemistry. 65:223-237.

34. Sternberger, L. A. 1979. Immunofluorescence. In Immunocytochemistry. L. A. Sternberger, editor. John Wiley \& Sons, Inc., New York. 24-58

35. Stefan, Y., M. Ravazzola, S. Grasso, A. Perrelet, and L. Orci. 1982. Glicentin precedes glucagon in the developing human pancreas. Endocrinology. 110:2189-2191.

36. Stefan, Y., S. Grasso, A. Perrelet, and L. Orci. 1983. A quantitative immunofluorescent study of the endocrine cell populations in the developing human pancreas. Diabetes. 32:293-301.

37. Sundler, F., J. Alumets, E. Ekblad, G. Böttcher, and R. Hakanson. 1985. Coexistence of peptides in the neuroendocrine system. In Biogenetics of Neurohormonal Peptides. R. Hakanson and J. Thorell, editors. Academic Press, Inc, London. 213-243.

38. Ullrich, A., J. Shine, J. Chirgwin, R. Pictet, E. Tischer, W. J. Rutter, and H. M. Goodman. 1977. Rat insulin genes: construction of plasmids containing the coding sequences. Science (Wash. DC). 196: 1313-1349.

39. Bell, G. I., R. Pictet, W. J. Rutter, B. Cordell, E. Tischer, and H. M. Goodman. 1980. Sequence of the human insulin gene. Nature (Lond.). 284:26-32.

40. Richter, K., E. Kawashima, R. Egger, and G. Kreil. 1984. Biosynthesis of thyrotropin-releasing hormone in the skin of Xenopus laevis: partial sequence of the precursor deduced from cloned cDNA. EMBO (Eur. Mol. Biol. Organ.) J. 3:617-621.

41. Lechan, R. M., P. Wu, I. M. D. Jackson, H. Wolf, S. Cooperman, G. Mandel, and R. H. Goodman. 1986. Thyrotropin-releasing hormone precursor-characterization in rat brain. Science (Wash. DC). 231:159161.

42. Jackson, I. M. D., P. Wu, and R. M. Lechan. 1985. Immunohistochemical localization in the rat brain of the precursor for thyrotropinreleasing hormone. Science (Wash. DC). 229:1097-1099.

43. Like, A. A., and L. Orci. 1972. Embryogenesis of the human pancreatic islets: a light and electron microscopic study. Diabetes. 21(Suppl. 2):511-534.

44. Adesanya, T. I., R. A. I. Grillo, and K. Shima. 1966. Insulin content and enzyme histochemistry of the human foetal pancreatic islet. J. Endocrinol. 36:151-158.

45. Winters, A. J., R. L. Eskay, and J. C. Porter. 1974. Concentration and distribution of TRH and LRH in the human fetal brain. J. Clin. Endocrinol. Metab. 39:960-963.

46. Theodoropoulos, T. J., and J. C. Zolman. 1985. Thyrotropin releasing hormone biosynthesis in neonatal rat pancreas. Endocrinol. Exp. 19:77-82.

47. Morley, J. E., S. R. Levin, M. Pehlevanian, R. Adachi, A. E. Pekary, and J. M. Hershman. 1979. The effects of thyrotropin-releasing hormone on the endocrine pancreas. Endocrinology. 104:137-139. 